2012-03-01

\title{
Physicochemical and Microbiological quality of harvested rainwater from an agricultural installation in Ireland
}

\author{
Sean O'Hogain \\ Technological University Dublin, Sean.Ohogain@tudublin.ie \\ Liam McCarton \\ Technological University Dublin, liam.mccarton@tudublin.ie \\ Niamh Mclntyre \\ City Analysts Ltd
}

See next page for additional authors

Follow this and additional works at: https://arrow.tudublin.ie/engschcivart

Part of the Environmental Health and Protection Commons, Environmental Indicators and Impact Assessment Commons, Sustainability Commons, and the Water Resource Management Commons

\section{Recommended Citation}

O'Hogain,S, McCarton,L, McIntyre,N,Pender,J,Reid,A; Physicochemical and microbiological quality of harvested rainwater from an agricultural installation in Ireland, Water and Environment Journal Promoting Sustainable Solutions, Volume 26, March 2012, Number 1. Chartered Institution of Water and Environmental Management. doi:10.21427/D73S5Z

This Article is brought to you for free and open access by the School of Civil and Structural Engineering at ARROW@TU Dublin. It has been accepted for inclusion in Articles by an authorized administrator of ARROW@TU

Dublin. For more information, please contact arrow.admin@tudublin.ie, aisling.coyne@tudublin.ie, gerard.connolly@tudublin.ie.

Funder: National Federation of Group Water Schemes, Department of Environment, Heritage \& Local Government

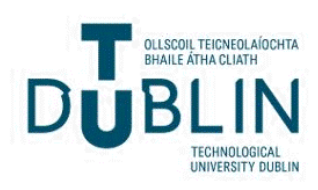




\section{Authors}

Sean O'Hogain, Liam McCarton, Niamh McIntyre, Jenny Pender, and Anna Reid

This article is available at ARROW@TU Dublin: https://arrow.tudublin.ie/engschcivart/31 


\title{
Physicochemical and microbiological quality of harvested rainwater from an agricultural installation in Ireland
}

\author{
S. O’Hogain, L. McCarton, N. McIntyre, J. Pender \& A. Reid \\ DTC Research Group, School of Civil and Building Services Engineering, Dublin Institute of Technology, Dublin, Ireland
}

Pre-publication Unedited Version

Keywords

agricultural rainwater harvesting; harvested rainwater quality; microbiological analysis; physicochemical analysis; water Standards

Correspondence

Liam McCarton, School of Civil and Building Services Engineering, Dublin Institute of Technology, Bolton Street, Dublin 1, Ireland.

Email: liam.mccarton@dit.ie

\begin{abstract}
DTC Research Group. Dublin Institute of Technology was commissioned in 2005 by the Department of Environment, Heritage and Local Government in Ireland to assess the feasibility of utilising rainwater to replace treated mains water for nonpotable uses. The project involved the design, installation, commissioning and monitoring of rainwater harvesting on a farm. Two monitoring programmes, Regime 1 and Regime 2, examined the physicochemical and microbiological quality of the harvested rainwater. Samples were taken monthly and tested. Regime 1 analysis showed that the microbiological quality of the rainwater from the site did not comply with the requirements of the European Communities Quality of Bathing Water Regulations, while the physicochemical quality complied with both Bathing and Drinking Water Standards with the exception of ammonia and lead. Regime 2 results showed a significant improvement and were compliant with the European Communities Quality of Bathing Water Regulations and showed near compliance with the European Communities Drinking Water Regulation.
\end{abstract}

\section{Introduction}

The recent socio-economic development in Ireland is posing problems for water supply infrastructures never intended to service the levels of demand being experienced. Water demand is typically met by importing large volumes of water from neighbouring catchments. All mains water in Ireland is treated to drinking water quality standards (O'Sullivan 2002). The main water-using sector in Ireland is Industry, 74\%, followed by Domestic use, $16 \%$, and Agriculture, $10 \%$ (World Resources Institute 2008). New water-efficient farming practices in Ireland such as innovative crop technologies, drip irrigation systems and rain water harvesting technologies will all need to be developed and applied (Curtin 2009). There are no National Water Quality Standards for Rainwater supply in Ireland.

This study addressed concerns over harvested rainwater quality by undertaking two sampling programmes to establish the quality of harvested rainwater in an Irish context and to examine the potential of using rainwater harvesting systems to replace treated mains water for nonpotable uses for agriculture. Two distinct sampling regimes were carried out. The first, a 12-month regime, was carried on the first installation. Modifications to this system have resulted in a second sampling regime, which is on going. The harvested rainwater was not disinfected or treated before testing.

\section{Materials and methods}

\section{Pilot agricultural rainwater harvesting site}

The agricultural site is located at Clonalvy, Co. Meath, approximately $50 \mathrm{~km}$ from Dublin. It is a 250 -acre livestock farm with 114 cattle and 50 calves as of March 2007. The farm buildings lie in the centre of the farm and the relevant buildings to the project are two sheds/barns, each of approximately $1000 \mathrm{~m}^{2}$ roof area. Potable water is supplied to the farm by Meath County Council.

\section{Agricultural rainwater harvesting system}

\section{Regime 1}

Figure 1 illustrates the rainwater water catchment network for the agricultural installation. Rainwater from two sheds/barns is drained by gravity to an underground precast $9 \mathrm{~m}^{3}$ concrete collection tank. A $200 \mathrm{~mm}$ high 75mm-diameter stainless steel mesh with $5 \mathrm{~mm}$ perforations 


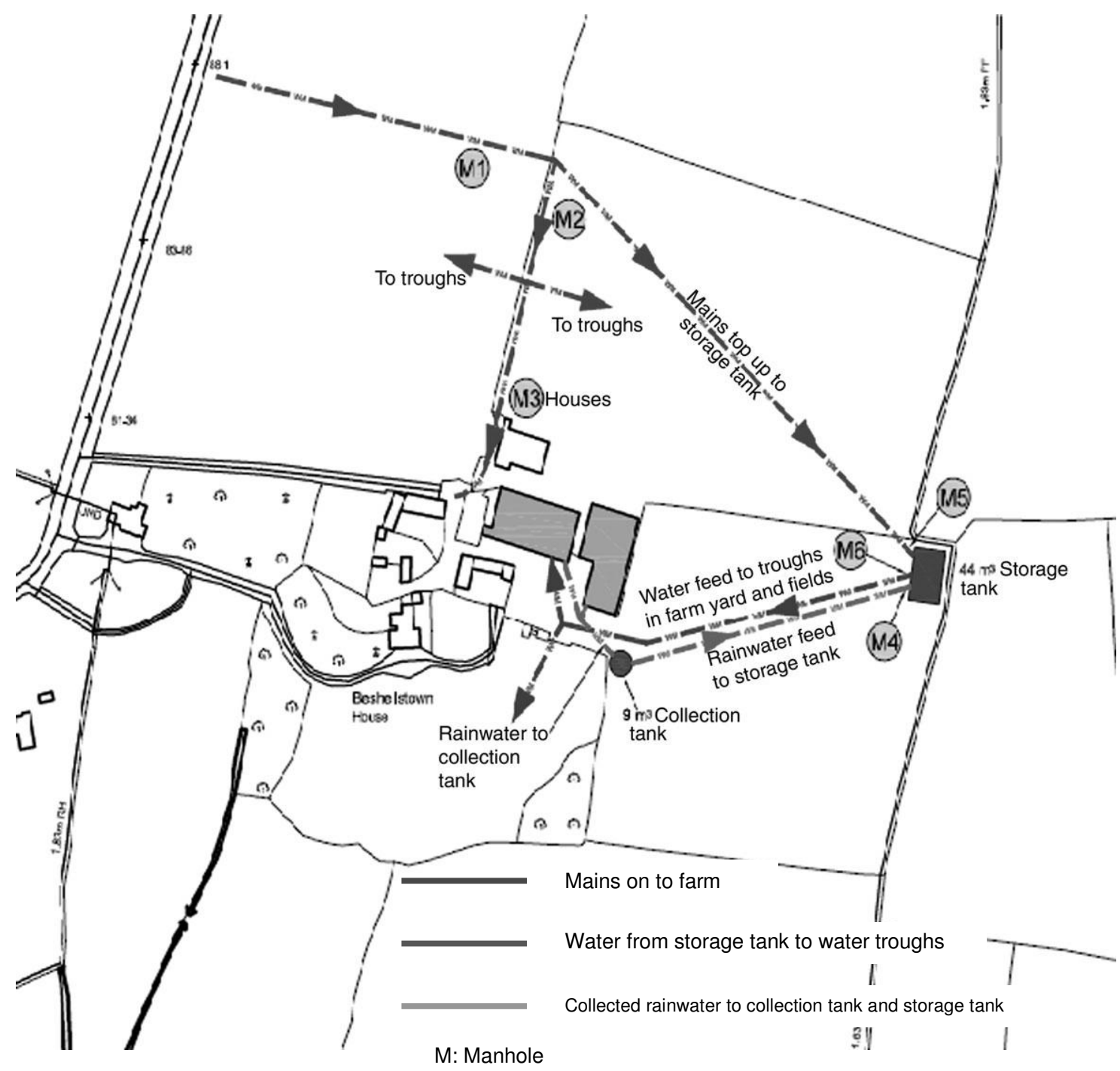

Fig. 1. Schematic of rainwater pilot installation, Clonalvy, Co. Meath.

was placed in the downpipe gutter as a filter. The collection tank was fitted with a pump and a float switch, and the overflow pipe was connected to an adjacent field drain. The harvested rainwater was pumped via a $25 \mathrm{~mm}$ rising pipe to two $22 \mathrm{~m}^{3}$ precast concrete reservoir tanks located on an adjacent elevated site. A mains top-up connection ensures mains water supply to the reservoir during periods of low rainfall. The harvested rainwater is distributed, via a $25 \mathrm{~mm}$ pipe, by gravity to supply the drinking troughs for cattle on the farm.

\section{Regime 2}

Owing to the unsatisfactory performance of elements of the original installation, it was decided to alter components of the Rainwater Harvesting system. A Lindab leafbeater ${ }^{\mathrm{TM}}$ and a BRAE ${ }^{\mathrm{TM}}$ filter were installed on the three downpipes conveying the rainwater, via the underground pipework, to the collection tank. The leafbeater was installed before the Brae filter. The design of the leafbeater is such that it allows the removal of larger solids, while the fine filter on the Brae traps the finer particles. The leafbeater is self-cleansing while the brae filter requires periodic cleaning of a removable mesh. The fine filter on the pump in the collection tank was also replaced. Manhole covers covering the underground pipework in the farmyard were sealed, using a silicon sealant.

\section{Testing methodology}

Rainwater from the underground reservoir was sampled monthly. Samples were taken aseptically and transported to the laboratory within $4 \mathrm{~h}$ and were stored at between 2 and $81 \mathrm{C}$ in accordance with ISO/IEC 17025:2005 (ISO/ 
IEC, 17025, 2005). The physicochemical analysis tested for chloride, nitrate, nitrite, sulphate, ammonia, $\mathrm{pH}$, total dissolved solids, total suspended solids, turbidity, sodium, calcium, lead, iron and cadmium. Samples for microbiological analysis were taken in sterile bottles to ensure no cross contamination. They were analysed for the timedependent parameters, coliforms, Escherichia coli, faecal coliforms, total viable counts (TVC) at 22 and $371 \mathrm{C}$ and

Pseudomonas spp. within $1 \mathrm{~h}$ of receipt in the laboratory (American Public Health Association/American Water Works Association/Water Environment Federation 2005). Coliforms and E. coli were analysed using the IDEXX Colibert 18 method. TVC at 22 and $371 \mathrm{C}$ were analysed as per the pour plate method. Faecal coliforms were analysed using the membrane filtration onto MFC Agar. Pseudomonas spp. were analysed using membrane filtration onto selective pseudomonas isolation agar. Analysis of water quality parameters was carried out in an Irish National Accreditation Body (INAB)-accredited laboratory.

\section{Results}

\section{Regime 1: physicochemical water quality}

Table 1 presents results for the harvested rainwater quality compared with the European Communities Drinking Water (No. 2) Regulations, S.I. No. 278 of 2007 (European Communities 2007) and the European Communities Quality of Bathing Water Regulations, S.I. 155 of 1992 (European Communities 1992) henceforth referred to as Drinking Water Regulations and Bathing Water Regulations, respectively). No disinfection programme was carried out at any stage in the rainwater harvesting process. It was considered an important function of the project to collect water quality data for untreated harvested rainwater. No first flush device was fitted to the system.

All of these parameters showed compliance with the European Communities Drinking Water (No. 2) Regulations. Results for turbidity, sodium, calcium and cadmium complied with both Drinking Water and Bathing Water Regulations. Three chemical parameters tested, iron, lead and ammonia, did not comply with the Drinking Water Regulations. Iron showed a mean of $61.50 \mathrm{mg} / \mathrm{L}$ and a maximum of $271.12 \mathrm{mg} / \mathrm{L}$, while lead had a mean of $3.28 \mathrm{~m}$ $\mathrm{g} / \mathrm{L}$ and a maximum of $15.46 \mathrm{mg} / \mathrm{L}$. Ammonia as $\mathrm{NH}_{3}$ breached the drinking water standard of $0.28 \mathrm{mg} / \mathrm{L}$ on a number of occasions. There is no maximum value for ammonia, iron and lead stipulated in the Bathing Water Regulations.

\section{Regime 1: microbiological water quality}

Table 2 presents the bacteriological monitoring results for the agricultural rainwater harvesting facility over the 12 month sampling period between January 2006 and January 2007. These results exceeded both the Drinking Water and the Bathing Water Regulations.

\section{Regime 2: physicochemical water quality}

Table 3 presents the physicochemical monitoring results for the agricultural rainwater harvesting facility over the 4-month sampling period between January 2008 and April 2008. All parameters except ammonia showed compliance with both the Bathing Water and Drinking Water Regulations. Ammonia as $\mathrm{NH}_{3}$ showed a mean value of $11.11 \mathrm{mg} / \mathrm{L}$ and a maximum of $41.58 \mathrm{mg} / \mathrm{L}$. This parameter breached the drinking water standard of

\begin{tabular}{|c|c|c|c|c|c|c|c|c|}
\hline & & & & & & & Drinking water & Bathing water \\
\hline Parameter & Units & Mean & Min & Max & $\mathrm{SD}$ & Median & guideline & guideline \\
\hline Chloride & $\mathrm{mg} / \mathrm{L}$ & 3.83 & o0.01 & 27.83 & 7.37 & 1.49 & $250 \mathrm{mg} / \mathrm{L}$ & \\
\hline Nitrate as $\mathrm{NO}_{3}$ & $\mathrm{mg} / \mathrm{L}$ & 1.23 & o0.01 & 2.84 & 0.92 & 1.20 & $50 \mathrm{mg} / \mathrm{L}$ & \\
\hline Nitrite as $\mathrm{NO}_{2}$ & $\mathrm{mg} / \mathrm{L}$ & 0.04 & o0.01 & 0.20 & 0.06 & 0.03 & $0.50 \mathrm{mg} / \mathrm{L}$ & \\
\hline Sulphate & $\mathrm{mg} / \mathrm{L}$ & 3.35 & o0.01 & 37.40 & 10.26 & 0.30 & $250 \mathrm{mg} / \mathrm{L}$ & \\
\hline Ammonia as $\mathrm{NH}_{3}$ & $\mathrm{mg} / \mathrm{L}$ & 1.35 & 0.11 & 7.16 & 1.91 & 0.56 & $0.28 \mathrm{mg} / \mathrm{L}$ & \\
\hline $\mathrm{pH}$ & $\mathrm{pH}$ units & 7.07 & 6.67 & 7.83 & 0.31 & 6.98 & $6.5-9.5$ & $6.0-9.0$ \\
\hline TDS & $\mathrm{mg} / \mathrm{L}$ & 59.15 & 15.00 & 174.00 & 48.75 & 49.00 & & \\
\hline TSS & $\mathrm{mg} / \mathrm{L}$ & 5.23 & 2.00 & 22.00 & 5.82 & 3.00 & & \\
\hline Turbidity & NTU & 0.63 & $\mathrm{o} 0.01$ & 2.10 & 0.75 & 0.40 & NAC and ATC & \\
\hline Sodium & $\mathrm{mg} / \mathrm{L}$ & 2.62 & o0.01 & 16.40 & 4.33 & 1.50 & $200 \mathrm{mg} / \mathrm{L}$ & \\
\hline Calcium & $\mathrm{mg} / \mathrm{L}$ & 5.43 & $\mathrm{o} 0.01$ & 46.80 & 12.89 & 1.40 & None & \\
\hline Lead, total & $\mathrm{mg} / \mathrm{L}$ & 3.28 & o0.01 & 15.46 & 4.66 & 2.21 & $10 \mathrm{mg} / \mathrm{L}^{\mathrm{a}}$ & \\
\hline Iron, total & $\mathrm{mg} / \mathrm{L}$ & 61.50 & $\mathrm{o} 0.01$ & 271.12 & 66.98 & 57.75 & $200 \mathrm{mg} / \mathrm{L}$ & \\
\hline Cadmium, total & $\mathrm{mg} / \mathrm{L}$ & o 0.01 & o0.01 & 00.01 & $\mathrm{o} 0.01$ & o0.01 & $5.0 \mathrm{mg} / \mathrm{L}$ & \\
\hline
\end{tabular}

aThe Regulations impose a parametric value of $25 \mathrm{mg} / \mathrm{L} \mathrm{Pb}$ until the 25 December 2013 after which the parametric value of $10 \mathrm{mg} / \mathrm{L}$ becomes effective. 
Table 2 Overall microbiological results for the harvested rainwater based on 14 monthly samples taken between January 2006 and January 2007

\begin{tabular}{|c|c|c|c|c|c|c|c|c|}
\hline Parameter & Units & Mean & Min & $\operatorname{Max}$ & SD & Median & $\begin{array}{l}\text { Drinking water } \\
\text { guideline }\end{array}$ & $\begin{array}{l}\text { Bathing water } \\
\text { guideline }\end{array}$ \\
\hline Coliforms & MPN/100 mL & 5171.36 & 13.50 & 48800 & 13241.35 & 920.80 & $0 / 100 \mathrm{~mL}$ & $5000 / 100 \mathrm{~mL}$ \\
\hline Escherichia coli & MPN/100 mL & 259.62 & 00.01 & 2419.60 & 653.68 & 48.20 & $0 / 100 \mathrm{~mL}$ & $1000 / 100 \mathrm{~mL}$ \\
\hline Faecal coliforms & CFU/100 mL & 83.92 & 00.01 & 600.00 & 160.35 & 30.00 & & $1000 / 100 \mathrm{~mL}$ \\
\hline TVC at $221 \mathrm{C}$ & $\mathrm{CFU} / \mathrm{mL}$ & 5291.90 & 00.01 & 16800.00 & 5513.60 & 3684.00 & NAC & \\
\hline TVC at $371 \mathrm{C}$ & $\mathrm{CFU} / \mathrm{mL}$ & 2898.77 & 2.00 & 31500.00 & 8615.99 & 431.00 & NAC & \\
\hline Pseudomonas spp & CFU/100 mL & 62.25 & $\mathrm{o} 0.01$ & 299.00 & 86.68 & 33.00 & $0 / 100 \mathrm{~mL}$ & \\
\hline
\end{tabular}

Table 3 Regime 2 overall physicochemical results for the harvested rainwater based on 3 monthly samples taken between January 2008 and April 2008

\begin{tabular}{|c|c|c|c|c|c|c|c|c|}
\hline Parameter & Units & Mean & Min & $\operatorname{Max}$ & $\mathrm{SD}$ & Median & $\begin{array}{l}\text { Drinking water } \\
\text { guideline }\end{array}$ & $\begin{array}{l}\text { Bathing water } \\
\text { guideline }\end{array}$ \\
\hline Chloride & $\mathrm{mg} / \mathrm{L}$ & 6.94 & $\mathrm{o} 0.01$ & 18.75 & 8.16 & 4.51 & $250 \mathrm{mg} / \mathrm{L}$ & \\
\hline Nitrate as $\mathrm{NO}_{3}$ & $\mathrm{mg} / \mathrm{L}$ & 4.68 & 1.77 & 8.99 & 3.10 & 3.98 & $50 \mathrm{mg} / \mathrm{L}$ & \\
\hline Nitrite as $\mathrm{NO}_{2}$ & $\mathrm{mg} / \mathrm{L}$ & 0.01 & $\mathrm{o} 0.01$ & 0.03 & 0.02 & 0.02 & $0.50 \mathrm{mg} / \mathrm{L}$ & \\
\hline Sulphate & $\mathrm{mg} / \mathrm{L}$ & 3.40 & 1.00 & 7.30 & 2.85 & 2.65 & $250 \mathrm{mg} / \mathrm{L}$ & \\
\hline Ammonia as $\mathrm{NH}_{3}$ & $\mathrm{mg} / \mathrm{L}$ & 11.11 & 0.63 & 41.58 & 20.32 & 1.11 & $0.28 \mathrm{mg} / \mathrm{L}$ & \\
\hline $\mathrm{pH}$ & $\mathrm{pH}$ units & 6.33 & 5.69 & 7.00 & 0.56 & 6.32 & $6.5-9.5$ & $6.0-9.0$ \\
\hline TDS & $\mathrm{mg} / \mathrm{L}$ & 54.50 & 24.00 & 84.00 & 26.10 & 55.00 & & \\
\hline TSS & $\mathrm{mg} / \mathrm{L}$ & 3.25 & 1.00 & 5.00 & 1.71 & 3.50 & & \\
\hline Turbidity & NTU & 1.82 & 0.37 & 4.30 & 1.72 & 1.31 & NAC and ATC & \\
\hline Sodium & $\mathrm{mg} / \mathrm{L}$ & 5.46 & 0.09 & 13.69 & 5.84 & 4.03 & $200 \mathrm{mg} / \mathrm{L}$ & \\
\hline Calcium & $\mathrm{mg} / \mathrm{L}$ & 10.40 & 3.90 & 22.90 & 8.91 & 7.40 & None & \\
\hline Lead, total & $\mathrm{mg} / \mathrm{L}$ & 5.32 & 2.63 & 8.16 & 2.34 & 5.24 & $10 \mathrm{mg} / \mathrm{L}^{\mathrm{a}}$ & \\
\hline Iron, total & $\mathrm{mg} / \mathrm{L}$ & 59.75 & 20.80 & 105.00 & 38.23 & 56.59 & $200 \mathrm{mg} / \mathrm{L}$ & \\
\hline Cadmium, total & $\mathrm{mg} / \mathrm{L}$ & 0.30 & 0.20 & 0.40 & 0.12 & 0.30 & $5.0 \mathrm{mg} / \mathrm{L}$ & \\
\hline
\end{tabular}

aThe Regulations impose a parametric value of $25 \mathrm{mg} / \mathrm{L} \mathrm{Pb}$ until the 25 December 2013 after which the parametric value of $10 \mathrm{mg} / \mathrm{L}$ becomes effective.

Table 4 Regime 2 overall microbiological results for the harvested rainwater based on 3 monthly samples taken between January 2008 and April 2008

\begin{tabular}{|c|c|c|c|c|c|c|c|c|}
\hline Parameter & Units & Mean & Min & $\operatorname{Max}$ & SD & Median & $\begin{array}{l}\text { Drinking water } \\
\text { guideline }\end{array}$ & $\begin{array}{l}\text { Bathing water } \\
\text { guideline }\end{array}$ \\
\hline Coliforms & MPN/100 mL & 73.93 & 3.10 & 275.50 & 134.41 & 8.55 & $0 / 100 \mathrm{~mL}$ & $5000 / 100 \mathrm{~mL}$ \\
\hline Escherichia coli & MPN/100 mL & 0.75 & $\mathrm{o} 0.01$ & 2.00 & 0.96 & 1.00 & $0 / 100 \mathrm{~mL}$ & $1000 / 100 \mathrm{~mL}$ \\
\hline Faecal coliforms & $\mathrm{CFU} / 100 \mathrm{~mL}$ & 1.50 & $\mathrm{o} 0.01$ & 5.00 & 2.38 & 1.0 & & $1000 / 100 \mathrm{~mL}$ \\
\hline TVC at $221 \mathrm{C}$ & $\mathrm{CFU} / \mathrm{mL}$ & 364.25 & 50.00 & 800.00 & 345.60 & 303.50 & NAC & \\
\hline TVC at $371 \mathrm{C}$ & $\mathrm{CFU} / \mathrm{mL}$ & 62.25 & 31.00 & 140.00 & 52.20 & 39.00 & NAC & \\
\hline Pseudomonas spp & $\mathrm{CFU} / 100 \mathrm{~mL}$ & 556.75 & 27.00 & 2000.00 & 962.78 & 100.00 & $0 / 100 \mathrm{~mL}$ & \\
\hline
\end{tabular}

$0.28 \mathrm{mg} / \mathrm{L}$ on the 4 monthly samples. There is no maximum value for ammonia stipulated in the Bathing Water Regulations.

\section{Regime 2: microbiological water quality}

Table 4 presents the bacteriological monitoring results for the agricultural rainwater harvesting facility over the 4-month sampling period between January 2008 and April 2008. These results complied with the Bathing Water Regulations and exceeded the Drinking Water Regulations.

\section{Rainfall characteristics}

Table 5 presents the rainfall characteristics for each of the testing regimes. The results show variations in rainfall intensities and total monthly rainfall depth (Met Eireann 2006).

\section{Discussion of results}

\section{Regime 1}

All results were obtained without any form of disinfection or the use of a first flush device. The microbiological 


\begin{tabular}{|c|c|c|c|c|c|c|}
\hline & $\begin{array}{l}\text { Total monthly } \\
\text { rainfall }(\mathrm{mm})\end{array}$ & $\begin{array}{l}\text { Max daily } \\
\text { rainfall (mm) }\end{array}$ & $\begin{array}{l}\text { Number of days } \\
\text { with no rainfall/rainfall } \\
\text { o0.2mm }\end{array}$ & $\begin{array}{l}\text { Number of days } \\
\text { with rainfall } \\
\text { Z0.2 mm }\end{array}$ & $\begin{array}{l}\text { Number of days } \\
\text { with rainfall } \\
\mathrm{Z} 2 \mathrm{~mm}\end{array}$ & $\begin{array}{l}\text { consecutive days with } \\
\text { no rainfall and/or } \\
\text { rainfall o0.2 mm }\end{array}$ \\
\hline \multicolumn{7}{|c|}{ Regime 1 January 2006-January 2007} \\
\hline January & 17 & 6.4 & 16 & 15 & 1 & 6 \\
\hline February & 30.4 & 7.4 & 15 & 13 & 8 & 6 \\
\hline March & 69.2 & 10.4 & 6 & 25 & 13 & 2 \\
\hline April & 32 & 6 & 12 & 17 & 8 & 4 \\
\hline May & 72.2 & 13.4 & 10 & 21 & 11 & 4 \\
\hline June & 7.2 & 3 & 17 & 4 & 2 & 15 \\
\hline July & 7.5 & 4 & 15 & 3 & 3 & 12 \\
\hline August & 0.51 & 0.51 & 7 & 1 & 0 & 7 \\
\hline September & 36.4 & 19.6 & 7 & 12 & 5 & 3 \\
\hline October & 54 & 8.6 & 13 & 18 & 8 & 5 \\
\hline November & 47 & 19.6 & 12 & 18 & 6 & 6 \\
\hline December & 72.4 & 15.6 & 7 & 24 & 10 & 2 \\
\hline January & 62 & 13.4 & 8 & 23 & 8 & 3 \\
\hline \multicolumn{7}{|c|}{ Regime 2 January 2008-April 2008} \\
\hline January & 72.8 & 12 & 10 & 21 & 15 & 5 \\
\hline February & 18.2 & 4.8 & 17 & 12 & 4 & 12 \\
\hline March & 28.2 & 5.6 & 1 & 15 & 6 & 1 \\
\hline April & 17.6 & 5.2 & 11 & 15 & 2 & 6 \\
\hline
\end{tabular}

results show that there is a major and consistent problem with the microbiological quality of the water. The levels of coliforms found in the water are sometimes in breach of the Bathing Water Regulations. The numbers of coliforms peaked twice at $3500 \mathrm{MPN} / 100 \mathrm{~mL}$ and at no stage was this system free from coliforms. In each sample taken, E. coli and faecal coliforms were also detected. The numbers of each detected were significant, with a maximum level of $48800 \mathrm{MPN} / 100 \mathrm{~mL}$ for E. coli and $600 \mathrm{CFU} /$ $100 \mathrm{~mL}$ for faecal coliforms.

The physicochemical results for Regime 1 were compliant with the Drinking Water Regulations, with the exception of iron, lead and ammonia. The presence of iron and lead in the water is likely as a result of leaching from the roof surface. The presence of ammonia as $\mathrm{NH}_{3}$ confirms the observations made in relation to the microbiological results, as ammonia is also an indicator of faecal contamination. The significance of high levels of ammonia in the water may have to be taken into account in any future chlorination of the system. The formation of chloramine compounds (which are much less potent disinfectants than free chlorine) by reaction between the added chlorine and the ammonia present in the water necessitates an increased use of chlorine if disinfection efficiencies are to be maintained (EPA 2001). The presence of cattle and their waste is ubiquitous in a farming context and therefore ammonia values are problematical when collecting rainwater on a farm. Sealing of the man- hole covers, while likely to reduce ammonia in the harvested rainwater, is unlikely to eliminate it altogether as the parameter is likely to be present in the atmosphere surrounding intensive cattle rearing operations.

\section{Sources of contamination}

The roof top has been reported as the source for the majority of contaminants entering rainwater harvesting systems (Simmons 2001). Microbiological contamination occurs through faecal contamination from birds and small mammals and leaves dropping from overlying vegetation. Other possible entry points at ground level within the catchment system include manholes, and the rainwater storage tank. Inefficient downpipe filters may also contribute to contamination of the rainwater tank by allowing contaminants from roof surface to enter the storage tank. Inspection of the system revealed a number of construction issues. The manhole covers were never properly sealed after installation. This provided a potential entry point for surface water from the farm yard containing animal waste and debris to enter the collection tank. It was also ascertained that the storage tank was left open for some time after installation and before commissioning of the system. The system was not flushed out or chlorinated before use meaning that there was no chance to remove any of this built up debris. 


\section{Regime 2}

Extensive work was carried out to the rainwater drainage network during August-October 2007 including the fitting of coarse and fine mesh filters to all downpipes and all manholes were sealed to eliminate potential contamination of the rainwater supply by the ingress of farmyard effluent. The collection tank was cleaned out on two occasions. With the completion of the new installation, four samples were taken in the period January 2008 to April 2008. Variations in rainfall characteristics combined with the limited number of samples taken during Regime 2 , give rise to some uncertainty in comparing results. The quality of the harvested rainwater for this period shows compliance with the Bathing Water regulations. Compliance with the Drinking water regulations was achieved with the exception of three parameters, two microbiological, coliforms and E. coli, and one physicochemical, nitrate as ammonia. The continuing high value for ammonia in the harvested water may be a feature of the agricultural environment. Coliforms and $\quad$ E. coli were detected in the harvested rainwater but at significantly reduced levels. The mean level of E. coli dropped from 260 to $0.75 \mathrm{MPN} / 100 \mathrm{~mL}$. This difference is likely to be caused by the cleaning of the storage tank combined with the sealing of the manholes eliminating surface contamination from the farmyard. It also confirms the importance of an efficient filter device to reduce the level of roof contaminants entering the system.

\section{Conclusions}

(1) The rainwater harvesting installation setup in Clonalvy, Co. Meath, referred to as Regime 2, supplied harvested rainwater, which complied with Bathing Water Regulations.

(2) The physicochemical results from the site during the initial period, referred to as Regime 1, supplied harvested rainwater, which complied with the Drinking Water Regulations over the sampling period, except for ammonia. The microbiological results breached both the Drinking and Bathing Water Regulations on all sampling dates.

(3) The results from the agricultural site illustrate the importance of the system design and construction on the harvested rainwater quality. Properly engineered and constructed systems can provide a potential onsite water resource for agriculture in Ireland.

\section{Acknowledgements}

The Authors gratefully acknowledge the assistance provided by the National Federation of Group Water Schemes, the Department of Civil \& Structural Engineering, Dublin Institute of Technology, Carlow County Council and City Analysts Ltd. Funding for the study was provided by the Department of Environment, Heritage \& Local Government through the National Rural Water Monitoring Committee.

\section{References}

American Public Health Association/American Water Works Association/Water Environment Federation. (2005)

Standard Methods for the Examination of Water and Wastewater (21st edn). American Public Health Association/American Water Works Association/Water Environment Federation, Washington, DC, USA.

Curtin, J. (2009) Positioning Ireland for the Coming Water Crisis [online]. http://www.iiea.com/blogosphere/ positioning-ireland-for-the-coming-water-crisis [accessed 17 March 2010].

Environmental Protection Agency. (2001) Parameters of Water Quality. Interpretation and Standards (ISBN 1-84095-0153). Environmental Protection Agency.

European Communities. (1992) Quality of Bathing Waters Regulations, S.I. No. 155 of 1992.

European Communities. (2007) Drinking Water No. 2 Regulations, S.I. No. 278 of 2007.

ISO/IEC, 17025. (2005) International Standard General Requirements for the Competence of Testing and Calibration Laboratories, ISO/IEC 2005. (ISBN 0-7337-7018-5). Standards Australia, Sydney, Australia.

Met Eireann. (2006) Climate of Ireland, Met Eireann [online]. http://www.met.ie/climate/climate-of-ireland.asp [accessed 15 May 2006].

O'Sullivan, G. (2002) Water Supply - The Supply/Demand Problem. Institution of Engineers of Ireland, Ballsbridge, Dublin, Ireland.

Simmons, G. (2001) Contamination of Potable Roof Collected Rainwater in Aukland, New Zealand. Water Res., 35, 1518-1524.

World Resources Institute. (2008) Review of Water Statistics by Country [online]. http://www.fao.org/nr/water/aquastat/ water_res/Ireland/index.stm [accessed 17 March 2010]. 